\title{
UJI KUALITAS BRIKET DARI TONGKOL JAGUNG DENGAN PEREKAT KANJI/PET DAN KOMPOSISI GAS BUANG PEMBAKARANNYA
}

\author{
HARYONO *, EVY ERNAWATI, SOLIHUDIN, DIAH AYU SUSILOWATI \\ Departemen Kimia, FMIPA, Universitas Padjadjaran \\ Jl. Raya Bandung-Sumedang Km.21 Jatinangor 45363, \\ Sumedang, Jawa Barat, Telp. 022-7796014 \\ *email : haryono@unpad.ac.id
}

\begin{abstract}
Abstrak. Limbah tongkol jagung merupakah salah satu limbah biomassa potensial di Indonesia sebagai bahan baku pembuatan briket. Briket termasuk bahan bakar terbarukan yang relatif lebih ramah ligkungan. Kualitas briket sangat dipengaruhi oleh berbagai faktor, diantaranya adalah jenis biomassa sebagai sumber karbon, jenis bahan pengikat, dan komposisi antara biomassa terhadap bahan pengikat. Polimer sintetik polietilen tereptalat memiliki sifat sebagai bahan pengikat pada pembuatan briket. Polietilen tereptalat banyak dijumpai sebagai limbah plastik. Penelitian ini bertujuan memanfaatkan limbah berupa tongkol jagung dan plastik polietilen tereptalat sebagai bahan pembuatan briket, dan mempelajari pengaruh komposisi arang tongkol jagung dan plastik polietilen tereptalat terhadap kualitas (sifat psikokimia) dan komposisi gas buang pembakaran briket. Komposisi bahan pembuatan briket divariasikan pada rasio berat arang tongkol jagung terhadap plastik sebesar 95:5, 90:10, dan 85:15. Kualitas briket diuji dan dibandingkan dengan SNI 01-6235-2000 tentang Briket Arang Kayu berdasarkan parameter nilai kalor, kadar air, kadar abu, dan kadar volatile matter. Hasil penelitian menunjukkan bahwa komposisi campuran bahan pembuat pada rasio berat antara arang tongkol jagung terhadap plastik polietilen tereptalat sebesar 95:5 menghasilkan briket dengan kualitas terbaik. Briket pada komposisi tersebut memenuhi standar kualitas menurut SNI briket arang kayu dan mengemisikan gas buang berupa hidrokarbon, karbon monoksida, dan nitrogen oksida dengan kadar paling rendah.
\end{abstract}

Kata kunci: briket, limbah plastik, polietilen tereptalat, tongkol jagung

\begin{abstract}
Corncob waste is one of the potential biomass wastes in Indonesia as a raw material for making briquettes. Briquettes include renewable fuels which are relatively more environmentally friendly. The quality of briquettes is influenced by various factors, including the type of biomass as a carbon source, the type of binder, and the composition of the biomass to the binder. Synthetic polymer of polyethylene terephthalate has properties as a binder for briquettes. Polyethylene terephthalate is often found as plastic waste. This study aims to utilize the waste in the form of corn cobs and polyethylene terephthalate plastics as briquette making materials, and study the influence of the composition of corn cobs charcoal and polyethylene terephthalate plastic on quality (psychochemical properties) and exhaust gas composition of briquette combustion. The composition of the briquette making material was varied in the ratio of the weight of corn cobs to plastic by $95: 5,90: 10$, and $85: 15$. The quality of briquettes is tested and compared with SNI 01-6235-2000 on Wood Charcoal Briquettes based on parameters of heat value, moisture content, ash content, and volatile matter levels. The results showed that the composition of the mixture of ingredients in the weight ratio between corncob charcoal to polyethylene terephthalate plastic of 95:5 was produced the best quality briquettes. Briquettes in the composition meet the quality standards according to SNI of wood charcoal briquettes and emit the exhaust gas in the form of hydrocarbons, carbon monoxide, and nitrogen oxides with the lowest levels.
\end{abstract}

Keywords: briquette, plastic waste, polyethylene terephthalate, corn cobs 


\section{Pendahuluan}

Komoditas tanaman pangan yang dibudidayakan di Indonesia sangat beragam, salah satunya adalah jagung. Produksi jagung tingkat nasional cenderung mengalami peningkatan. Pada tahun 2016, produksi jagung nasional sebesar 23,6 juta ton. Nilai tersebut meningkat menjadi 28,9 juta ton pada tahun 2017 dan 30 juta ton pada tahun 2018 [1]. Produksi jagung yang tinggi di Indonesia tersebut berdampak pada melimpahnya tongkol jagung yang dihasilkan. Pada limbah jagung terdapat sekitar 17,24\% tongkol jagung [2], dengan komposisi kimia basis kering terdiri dari 38,8\% selulosa, 44,4\% hemiselulosa, dan 11,9\% lignin [3]. Komposisi kimia dari tongkol jagung tersebut menjadikan tongkol jagung merupakan limbah biomassa potensial. Sebagai bahan bahan baku terbarukan, tongkol jagung sangat potensial untuk pembuatan berbagai jenis biofuel, salah satunya adalah briket.

Briket merupakan bahan bakar padat ramah lingkungan dan bersifat terbarukan sehingga pemanfaatannya sebagai bahan bakar dapat mengurangi dampak negatif penggunaan bahan bakar fosil atau konvensional. Briket dihasilkan dari teknologi pembriketan. Pembriketan diterapkan dengan maksud untuk memperbaiki sifatsifat fisik dan nilai kalor limbah biomassa agar menjadi material atau bahan baru dengan sifat-sifat tertentu, mudah ditangani, dan meningkat nilai kalornya $[4,5]$. Beberapa jenis biomassa telah dipelajari sebagai bahan baku pembuatan briket, seperti batang gandum [6], serpihan sabut kelapa dan kulit padi [7], dan debu batubara [4].

Kualitas briket dari proses pembriketan dipengaruhi oleh berbagai faktor. Jenis biomassa, kondisi karbonisasi (suhu dan waktu), kondisi pembriketan (tekanan, jenis alat pembriket/penekan), dan jenis binder atau bahan pengikat briket merupakan faktor-faktor yang harus diperhatikan pada proses pembuatan briket [8]. Binder pada tahap pembriketan sangat dibutuhkan jika biomassa sebagai bahan baku briket memiliki densitas curah, kadar lignin, kadar karbohidrat mampu larut dalam air, dan kadar protein rendah, karena bahan-bahan kimia tersebut mampu membentuk jembatan ikatan antar butiran-butiran arang [9]. Kanji, tanah liat, tar kayu, pitch, dan molases merupakan bahan umum binder [8]. Selain bahan-bahan tersebut, polimer sintetik dalam bentuk limbah plastik memiliki syarat sebagai binder melalui tahap pelelehan. I.Y. Zakari el al. telah menginvestigasi pengaruh penambahan binder dari bahan PVC terhadap nilai kalor briket dari limbah pertanian. Limbah plastik potensial lainnya sebagai binder adalah plastik dari bahan PET (polyethylene terephthalate) [10].

Tujuan penelitian ini adalah mempelajari pengaruh kadar plastik PET sebagai binder pembantu terhadap kualitas briket dan komposisi gas buang pembakarannya. Kualitas briket ditentukan dengan merujuk pada standar kualitas briket arang kayu menurut SNI 01-6235-2000 berdasarkan parameter nilai kalor, kadar air, kadar abu, dan kadar volatile matter [11].

\section{Metode Penelitian}

Penelitian dilakukan dalam tiga tahap utama, yaitu: karbonisasi tongkol jagung, pembriketan arang tongkol jagung dengan memvariasikan kadar PET sebagai binder pembantu dari binder utama berupa kanji, dan uji kualitas serta analisis gas buang pembakaran briket. 


\subsection{Karbonisasi Tongkol Jagung}

Tahap karbonisasi biomassa dilakukan untuk memperoleh arang. Tongkol jagung dipotong ke arah memanjang setebal sekitar 1,0 cm kemudian dicuci dengan air bersih. Potongan tongkol jagung dikeringkan dalam oven pada suhu $105{ }^{\circ} \mathrm{C}$ selama 2 jam untuk mengurangi kadar air bebas. Selanjutnya potongan tongkol jagung kering dikarbonisasi pada suhu $450{ }^{\circ} \mathrm{C}$ selama 30 menit di dalam muffle furnace (Thermoline ${ }^{\mathrm{TM}}, 100-1200{ }^{\circ} \mathrm{C}$ ) dengan laju kenaikan suhu $10{ }^{\circ} \mathrm{C} / \mathrm{menit}$.

Arang tongkol jagung hasil karbonisasi didinginkan. Arang kumudian diperkecil ukurannya dengan mortar, dan diayak dengan pengayak mekanik getar untuk diperoleh serbuk arang berukuran lolos 40 mesh $(0,42 \mathrm{~mm})$.

\subsection{Tahap Pembriketan}

Bahan binder berupa plastik bekas jenis PET dicuci sampai bersih dan dikeringkan. Plastik PET selanjutnya dipotong dengan ukuran $0,5 \mathrm{~cm}$ x $0,5 \mathrm{~cm} .100 \mathrm{~g}$ campuran arang tongkol jagung dan binder PET disiapkan dengan variasi komposisi campuran arang dan PET pada rasio berat 95:5, 90:10, dan 85:15. Selanjutnya campuran arang dan PET tersebut dicampur lagi dengan binder kanji dan air masing-masing sebanyak 7 dan 15\% terhadap berat campuran arang dan PET.

Campuran arang tongkol jagung dan binder dibriketkan dengan alat pembriket tipe hand presses. Pembriketan dilakukan pada tekanan 7 MPa yang diaplikasikan pada cetakan briket berdiameter $7,5 \mathrm{~cm}$. Kemudian agar fungsi plastik PET sebagai binder dapat bekerja, briket hasil pengepresan dipanaskan dalam muffle furnace pada suhu $500{ }^{\circ} \mathrm{C}$ selama 15 menit (Thermoline ${ }^{\mathrm{TM}}, 100-1200{ }^{\circ} \mathrm{C}$ ) dengan laju kenaikan suhu $10^{\circ} \mathrm{C} /$ menit. Briket yang dihasilkan dari variasi komposisi campuran arang dan PET pada rasio berat 95:5, 90:10, dan 85:15 berturut-turut diberi simbol B1, B2, dan B3.

\subsection{Tahap Uji Kualitas Briket dan Analisis Gas Buang Pembakaran Briket}

Briket yang dihasilkan dari setiap variasi komposisi arang dan PET diuji kualitasnya berdasarkan parameter nilai kalor, kadar air, kadar abu, dan kadar volatile matter (SNI 01-6235-2000). Sedangkan evaluasi briket sebagai bahan bakar ramah lingkungan dipantau melalui hasil analisis jenis dan komposisi gas buang dari pembakaran briket.

Nilai kalor briket dianalisis dengan kalorimeter bom IKA Model C 2000. Nilai kalor yang diperoleh merupakan HHV (high heating value) dari sampel briket. Kadar air, abu, dan volatile matter ditentukan dengan metode gravimetri. Hanatech Ultra 4/5 Gas Analyzer Model IM 2400 digunakan untuk menentukan jenis dan komposisi gas buang yang dihasilkan dari pembakaran sampel briket

\section{Hasil dan Pembahasan}

\subsection{Penampilan Fisik Briket}

Pembuatan briket dari tongkol jagung dengan variasi komposisi antara arang tongkol jagung dan plastik PET pada rasio berat arang terhadap PET sebesar 95:5, 90:10, dan 85:15 dihasilkan briket dengan penampilan fisik tertentu. Perbandingan penampilan fisik briket dari ketiga variasi rasio tersebut ditampilkan pada Gambar 1. 


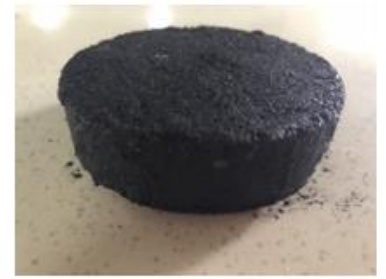

(B1)

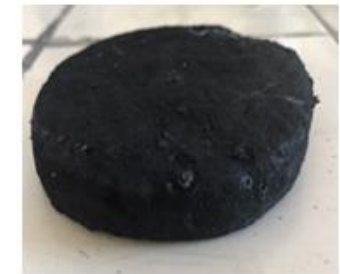

(B2)

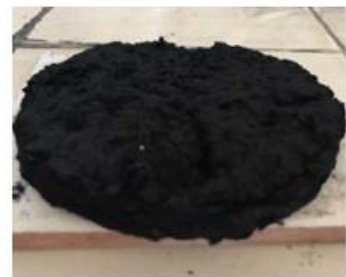

(B3)

Gambar 1. Perbandingan penampilan fisik dari briket yang dihasilkan dari berbagai variasi rasio berat arang tongkol jagung terhadap PET $(B 1=95: 5, B 2=90: 10, B 3=85: 15)$

Gambar 1 menunjukkan B1 (Briket 1) dan B2 (Briket 2) yang merupakan briket dengan rasio berat antara arang tongkol jagung terhadap PET masing-masing sebesar 95:5 dan 90:10 memiliki penampilan fisik berwarna hitam, tidak rapuh (kompak), dan berbentuk utuh. Sedangkan B3 (Briket 3) berwarna hitam dan tidak rapuh, namun bentuk briket relarif tidak utuh (permukaannya tidak rata). Ketidakutuhan bentuk atau ketidakrataan permukaan briket menunjukkan bahwa peran PET sebagai binder (pembentuk jembatan ikatan antar butiran arang) kurang berfungsi dengan baik. Hal tersebut diduga dengan semakin banyaknya PET ditambahkan sebagai binder bersama binder utama (air kanji), gaya tolak-menolak antara molekul PET dengan air kanji akan semakin meningkat. A.E. Wiacek et al. menyatakan bahwa PET bersifat hidrofob, dan sifat adhesif serta kehidrofilikannya akan meningkat jika dimodifikasi dengan kanji [12]. Kanji lebih bersifat hidrofilik. Oleh karena itu, pemakaian PET dalam jumlah semakin banyak dalam campurannya dengan air kanji sebagai binder akan mengurangi adhesivitas binder terhadap butiran-butiran arang pada proses pembriketan.

\subsection{Uji Kualitas Briket}

Pada penelitian ini, parameter kualitas briket yang uji meliputi nilai kalor, kadar air, kadar abu, dan kadar volatile matter. Untuk menentukan kelayakan kualitas dari sampel briket tongkol jagung, hasil uji setiap parameter kualitas tersebut dibandingkan dengan syarat kualitas briket menurut SNI 01-6235-2000 tentang Kualitas Briket Arang Kayu. Gambar 2 menampilkan hasil uji nilai kalor dan perbandingannya dengan nilai kalor briket menurut SNI.

SNI tentang Briket Arang Kayu mensyaratkan nilai kalor minimal dari briket sebesar $5000 \mathrm{kal} / \mathrm{g}$. Seperti ditampilkan pada Gambar 2, ketiga sampel briket (B1, B2, dan B3) dari berbagai variasi jumlah penambahan PET sebagai binder pembantu memiliki nilai kalor melebihi ketentuan SNI 01-6235-2000. Sedangkan penambahan PET dengan jumlah semakin banyak, mengakibatkan peningkatan nilai kalor dari briket yang dihasilkan. Berdasarkan formulasi bahan pembuat briket, peningkatan jumlah pemakaian PET berimplikasi pada semakin sedikitnya arang tongkol jagung yang digunakan. Dengan demikian, peningkatan nilai kalor dari briket merupakan dampak dari semakin banyaknya penggunaan PET dalam formulasi bahan. Dari perhitungan, terjadi peningkatan nilai kalor rata-rata sebesar 1,12\% sebagai akibat dari peningkatan jumlah PET sebanyak 5\% pada setiap formulasi bahan pembuat briket. Data-data tersebut menunjukkan bahwa PET 
selain berfungsi sebagai binder pembantu, juga berperan dalam meningkatkan nilai kalor briket yang dihasilkan. Peran tambahan ini dimungkinkan hanya jika nilai kalor dari PET lebih besar daripada nilai kalor arang tongkol jagung. Nilai kalor arang tongkol jagung sebesar 3983,25 kal/g [9]. Sedangkan PET memiliki nilai kalor sebesar 6124,40 kal/g [13]. Selain itu keberadaan kanji juga berkontribusi terhadap nilai kalor briket.

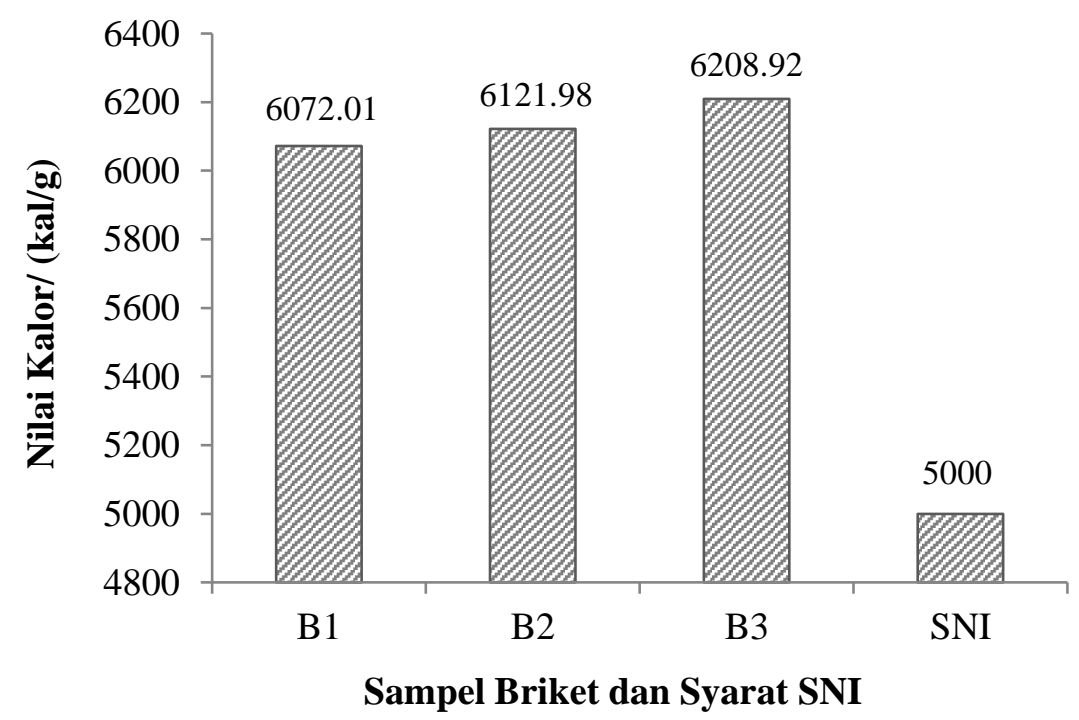

Gambar 2. Nilai kalor briket tongkol jagung pada berbagai variasi rasio berat arang tongkol jagung terhadap PET dan perbandingannya dengan SNI (nilai kalor briket menurut SNI 01 $6235-2000=\min .5000 \mathrm{kal} / \mathrm{g}$ )

Jenis bahan binder berpengaruh terhadap nilai kalor briket. Sebagai perbandingan, penggunaan PVC sebagai binder pada pembuatan briket dari batang tanaman jagung menghasilkan briket dengan nilai kalor sebesar 10,98 MJ/kg atau sekitar $2626,79 \mathrm{kal} / \mathrm{g}$ [10]. Sedangkan S.Y. Kpalo et al. memperoleh briket dengan nilai kalor tertinggi sebesar $16,91 \mathrm{MJ} / \mathrm{kg}$ atau sekitar $4045,46 \mathrm{kal} / \mathrm{g}$ pada pembuatan briket dari campuran tongkol jagung dan kulit batang kelapa dengan bubur kertas bekas sebagai binder [9].

Parameter uji kualitas briket lainnya adalah kadar air, abu, dan volatile matter. Kadar air di dalam briket mempengaruhi usaha penyelaan awal briket. Sedangkan abu merupakan campuran berbagai oksida logam. Keberadaan air dan abu di dalam briket akan berdampak terhadap penurunan nilai kalor briket. Hal tersebut sebagai akibat sebagian panas yang dihasilkan pada pembakaran briket diserap oleh air untuk proses evaporasi dan abu untuk peningkatan suhunya. Volatile matter adalah bagian dari bahan bakar yang dilepaskan dalam bentuk gas atau uap berupa hidrokarbon atau gas lain sebagai hasil dekomposisi residu pada pemanasan terkontrol [14]. Sehingga keberadaan volatile matter di dalam briket mewakili pengotor berupa bahan-bahan organik yang tidak berhasil terkonversi menjadi karbon atau arang selama proses karbonisasi. Kadar volatile matter di dalam bahan bakar padat berhubungan dengan karakteristik pembakaran. Bahan bakar dengan kadar volatile matter tinggi cenderung memiliki nilai kalor lebih rendah dan timbul 
lebih banyak asap ketika dibakar [15]. Hasil uji kualitas ketiga parameter tersebut ditampilkan pada Tabel 1 .

Tabel 1. Hasil uji kadar air, abu, dan volatile matter dari briket tongkol jagung pada variasi komposisi arang dan binder PET serta perbandingannya dengan SNI

\begin{tabular}{cccc}
\hline \multirow{2}{*}{ Jenis briket } & \multicolumn{3}{c}{ Parameter uji } \\
\cline { 2 - 4 } & Kadar air/ \% & Kadar abu/ \% & Volatile matter/ \% \\
\hline B1 & 4,98 & 6,0 & 7,0 \\
B2 & 4,74 & 5,0 & 9,0 \\
B3 & 3,87 & 3,0 & 12,0 \\
SNI & Maks. 8,0\% & Maks. 8,0\% & Maks. 18\% \\
\hline
\end{tabular}

Data pada Tabel 1 menunjukkan bahwa briket dari semua variasi komposisi arang tongkol jagung dan PET memenuhi standar kualitas menurut SNI 01-6235-2000. Namun penentuan briket dengan kualitas terbaik masih akan dikonfirmasi dengan komposisi gas buang yang diemisikan pada pembakaran briket.

Kadar abu dan volatile matter dalam briket sangat dipengaruhi oleh jenis biomassa yang digunakan sebagai bahan baku sumber karbon [14] dan komposisi dari biomassa-binder [16]. Data hasil uji pada Tabel 1 menyatakan bahwa terdapat pengaruh konsisten peningkatan jumlah PET terhadap kadar air dan abu, dimana peningkatan jumlah PET (dengan demikian jumlah arang tongkol jagug semakin sedikit) menyebabkan penurunan kadar air dan abu. Hal tersebut mengindikasikan bahwa kadar air dan abu briket hanya merupakan kontribusi dari biomassa bahan pembuat briket (tongkol jagung). PET sebagai binder merupakan polimer sintetik dari bahan baku fraksi minyak bumi. Selain itu PET bersifat cenderung tidak mengikat air. Dengan demikian PET pada saat digunakan sebagai binder dapat dikatakan tidak mengandung kadar air dan abu. Sementara itu terdapat kecenderungan sebaliknya terhadap kadar volatile matter. Kadar volatile matter briket mengalami peningkatan seiring dengan penambahan PET dalam formulasi. Secara struktur kimia, PET merupakan hasil polimerisasi antara monomer berupa etilen tereptalat yang secara atomik tersusun dari atom $\mathrm{C}, \mathrm{H}$, dan O. Oleh karena itu penambahan jumlah PET dalam formulasi bahan baku briket akan berdampak peningkatan kadar $\mathrm{C}, \mathrm{H}$, dan $\mathrm{O}$ dalam bentuk senyawa polimer. Polimer tersebut berkontribusi pada pembentukan volatile matter melalui reaksi depolimerisasi, terutama dalam bentuk senyawa hidrokarbon rantai pendek, gas $\mathrm{CO}$, dan $\mathrm{NO}_{\mathrm{x}}$ selama tahap pengujian kadar volatile matter. Selain itu, kadar air pada briket dapat pula mengalami perubahan akibat kelembaban dan suhu udara dimana briket berkontak atau bersinggungan dengan udara selama penyimpanan [14].

\subsection{Analisis Komposisi Gas Buang Pembakaran Briket}

Analisis jenis dan komposisi gas buang dari briket dilakukan untuk mengetahui dampak lingkungan yang ditimbulkan dalam bentuk emisi gas-gas dengan sifatsifat yang tidak diinginkan, seperti tingkat toksisitas, keasaman, dan isu pemanasan global. Hasil analisis tersebut ditampilkan pada Gambar 3 dan Tabel 2. Gambar 3 menampilkan print-out hasil analisis dari gas analyzer terhadap gas buang yang diemisikan dari pembakaran ketiga sampel briket tongkol jagung. Sedangkan Tabel 
2 disajikan untuk mempermudah pembandingan jenis dan komposisi gas buang dari pembakaran ketiga sampel briket.

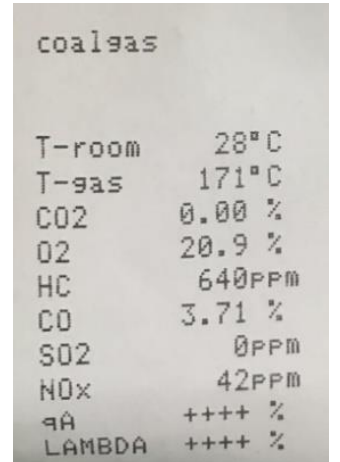

(B1)

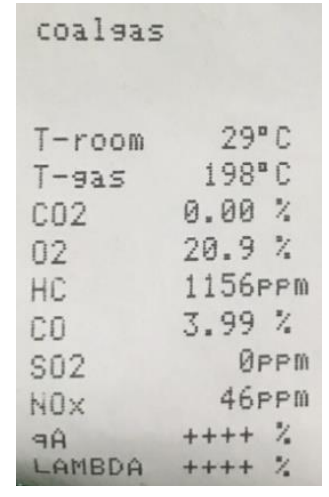

(B2)

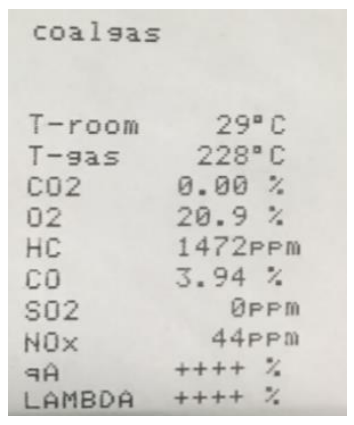

(B3)

Gambar 3. Perbandingan jenis dan komposisi gas buang dari pembakaran briket yang dihasilkan dari berbagai variasi rasio berat arang tongkol jagung terhadap PET

Tabel 2. Perbandingan jenis dan komposisi gas buang dari pembakaran briket yang dihasilkan dari berbagai variasi rasio berat arang tongkol jagung terhadap PET

\begin{tabular}{ccccccc}
\hline \multirow{2}{*}{ Jenis briket } & \multicolumn{7}{c}{ Komposisi gas buang } \\
\cline { 2 - 8 } & $\mathbf{C O}_{2}$ & $\mathbf{O}_{2}$ & $\mathbf{H C}$ & $\mathbf{C O}$ & $\mathbf{S O}_{2}$ & $\mathbf{N O}_{\mathbf{x}}$ \\
\hline B1 & 0,0 & $20,9 \%$ & $640 \mathrm{ppm}$ & $3,71 \%$ & 0,0 & $42 \mathrm{ppm}$ \\
B2 & 0,0 & $20,9 \%$ & $1156 \mathrm{ppm}$ & $3,99 \%$ & 0,0 & $46 \mathrm{ppm}$ \\
B3 & 0,0 & $20,9 \%$ & $1472 \mathrm{ppm}$ & 3,94 & 0,0 & $44 \mathrm{ppm}$ \\
\hline
\end{tabular}

Berdasarkan hasil analisis terhadap gas buang dari pembakaran sampel briket tongkol jagung, nampak bahwa ketiga briket mengemisikan gas $\mathrm{O}_{2}$ dalam kadar sama, yaitu 20,9\%. Pada pembakaran ketiga sampel briket juga tidak dijumpai adanya emisi gas $\mathrm{CO}_{2}$ dan $\mathrm{SO}_{2}$. Sedangkan untuk jenis gas buang hidrokarbon, $\mathrm{CO}$, dan $\mathrm{NO}_{\mathrm{x}}$, gas buang dari pembakaran B1 menghasilkan kadar paling kecil. Karena gas $\mathrm{HC}, \mathrm{CO}$, dan $\mathrm{NO}_{\mathrm{x}}$ merupakan gas-gas yang berkontibusi terhadap polusi udara dengan dampak negatifnya masing-masing, dan juga berdasarkan pertimbangan hasil penilaian penampilan fisik briket (Gambar 1) dan hasil uji kualitas briket, dapat disimpulkan bahwa briket yang dihasilkan dari formulasi rasio berat antara arang tongkol jagung terhadap PET sebesar 95:5 merupakan briket dengan kualitas terbaik.

\section{Kesimpulan}

Tongkol jagung nerupakan limbah biomass potensial sebagai bahan baku pembuatan briket. Penggunaan plastik bekas dari bahan PET sebagai binder pada pembuatan briket dari tongkol jagung berpengaruh terhadap kualitas briket yang dihasilkan berdasarkan parameter nilai kalor, kadar air, kadar abu, dan kadar volatile matter. Berdasarkan keempat parameter kualitas tersebut, semua briket tongkol jagung yang dihasilkan dari setiap variasi komposisi arang tongkol jagung 
dan PET telah memenuhu standar kualitas menurut SNI 01-6235-2000 tentang Briket Arang Kayu.

Peningkatan jumlah atau kadar PET sebagai binder pada formulasi bahan pembuatan briket mengakibatkan peningkatan nilai kalor dan kadar volatile matter briket. Kecenderungan sebaliknya dijumpai pada menurunnya kadar air dan abu dari briket.

Pembakaran briket dengan jumlah PET semakin sedikit cenderung mengemisikan gas-gas buang dengan kadar yang lebih ramah lingkungan. Oleh karena itu, dengan pertimbangan hasil penilaian tampilan fisik, uji kualitas, dan analisis gas buang, briket dengan kadar PET paling sedikit merupakan briket dengan kualitas terbaik.

\section{Daftar Pustaka}

1. Kementerian Pertanian, Produksi dan Kualitas Jagung Indonesia Tidak Kalah Saing dengan Impor, https://pertanian.go.id/home/?show=news\&act=view\&id =3933. 22 Agustus 2019 .

2. Y. Zhang, A.E. Ghaly, B. Li, Physical properties of corn residues, American Journal of Biochemistry and Biotechnology, Vol. 8, No. 2 (2012), p. 44-53.

3. M. Pointner, P. Kuttner, T. Obrlik, A. Jager, H. Kahr, Composition of corncobs as a substrate for fermentation of biofuels, Agronomy Research, Vol. 12, No. 2 (2014), p. 391-396.

4. T.K. Ajiboye, S. Abdulkareem, A.O.Y Anibijuwon, Investigation of mechanical properties of briquette product of sawdust-charcoal as a potential domestic energy source, J. Appl. Sci. Environ. Manage., Vol. 20, No. 4 (2016), p. 1179-1188.

5. O. McDougal, S. Eidemiller, N. Weires, Biomass briquettes: Turning waste into energy, http://biomassmagazine.com/articles/5148/biomass-briquettes-turningwaste-into-energy/. 23 November 2010

6. A. Dermibas, Physical properties of briquettes from waste paper and wheat straw mixtures, Energy Conversion and Management, Vol. 40, No. 4 (1999), p. 437-445.

7. Md. Hamidul Islam, Md. Mosharraf Hossain, Md. Abdul Momin, Development of briquette from coir dust and rice husk blend, Int. Journal of Renewable Energy Development, Vol. 3, No. 2 (2014), p. 119-123.

8. C. Heinze, M. Vis, L. Uitdewilligen, J. Vos, Charcoal production from alternative feedstocks, Final Report June 25 (2013), BTG Biomass Technology Group BV, Netherlands, p. 1-77.

9. S.Y. Kpalo, Md.F. Zainuddin, L.Abd. Manaf, A.M. Roslan, Production and characterization of hybrid briquettes from corncobs and oil palm trunk bark under a low pressure densification technique, J. Sustainability, Vol. 12, No. 2468, p. 1-16.

10. I.Y., Zakari, A. Ismaila, U., Sadiq, R. Nasiru, Investigation on the effects of addition of binder and particle size on the high calorific value of solid biofuel briquettes, Journal of Natural Sciences Research, Vol. 3, No. 12 (2013), p. 3034.

11. Badan Standardisasi Nasional (BSN), SNI 01-6235-2000 tentang Briket Arang Kayu (2000). 
12. A.E. Wiacek, M. Jurak, A. Gozdecka, M. Worzakowska, Interfacial properties of PET and PET/starch polimers developed by air plasma processing, Colloids and Surfaces A: Physicohemical and Engineering Aspects, Vol. 532 (2017), p. 323-331.

13. D.A. Tsiamis, M.J. Castaldi, Determining accurate heating values of nonrecycled plastics (NRP), Technical Report March 23 (2016), Earth Engineering Center, City University of New York, p. 1-27.

14. D. K. Vyas, F.G. Sayyad, M.S. Khardiwarm, S. Kumar, Physicochemical properties of briquettes from different feed stock, Current World Environment, Vol. 10, No. 1 (2015), p. 263-269.

15. Nurshalina binti Mohd Rani, Production of briquette from coffee waste, Master Thesis in Chemical Engineering Programme of Universiti Teknologi Petronas (May 2014), Tronoh, Perak, Malaysia.

16. G. Borowski, J.J. Hycnar, Utilization of fine coal waste as a fuel briquettes, International Journal of Coal Preparation and Utilization, Vol. 33 (2013), p. 194-204 